\title{
Kudzu Forage Quality Evaluation as an Animal Feed Source
}

\author{
Dylan Glass, Safaa Al-Hamdani* \\ Biology Department, Jacksonville State University, Jacksonville, USA \\ Email: "sah@jsu.edu
}

Received 26 January 2016; accepted 27 March 2016; published 30 March 2016

Copyright (C) 2016 by authors and Scientific Research Publishing Inc.

This work is licensed under the Creative Commons Attribution International License (CC BY). http://creativecommons.org/licenses/by/4.0/

(c) (i) Open Access

\section{Abstract}

The nutritional value of kudzu (Pueraria lobata) was evaluated as a potential animal feed. Randomly selected samples from natural habitats with Jacksonville area (Alabama, USA) were utilized in the study. Kudzu leaves showed significantly higher dry matter and crude protein content than the stems; whereas, ADF fiber was significantly lower in the leaves. However, NDF and total digestible nutrients (TDN) were similar in the leaves and the stems. The leaf part of kudzu was especially rich in CP $(24.46 \%)$ and met the requirements and recommendations for most ruminants. The TDN value for kudzu stem is $55.99 \%$, which falls below but within the recommended range. Macronutrients concentration between the stem and leaf of kudzu, nitrogen, calcium, and magnesium showed a significantly higher in the leaf than the stem. However, phosphorous was similar in concentration in the stem and the leaf, and potassium was higher in the stem. In regard to the micronutrients, the only significant difference between the leaf and the stem was iron. However, iron, manganese, zinc, and copper were all above the recommended concentrations by the National Research Council. In general, kudzu can be considered a good source for animal feed, especially the leaf, which shows a higher value in most of the determined criteria in comparison to what was recommended by the National Research Council. This should provide a new outlook to kudzu, which has been considered a noxious weed and help in the utilization of kudzu in a positive way in the southern region of the US.

\section{Keywords}

Kudzu (Pueraria lobata), Macronutrients, Micronutrients, Nutritive Value, Forage Quality

\section{Introduction}

Kudzu (Pueraria lobata) is a rapidly growing, high climbing perineal legume vine native to Japan [1]. Kudzu is

*Corresponding author.

How to cite this paper: Glass, D. and Al-Hamdani, S. (2016) Kudzu Forage Quality Evaluation as an Animal Feed Source. American Journal of Plant Sciences, 7, 702-707. http://dx.doi.org/10.4236/ajps.2016.74063 
a leguminous, weedy vine with pubescent stems, trifoliate leaves, and a perennial deep root system [2]. Kudzu has the potential to grow at a rate of 29 to 30 meters per growing season [3]. The dense packing of kudzu can result in tens of thousands of plants occupying a single acre of land. Furthermore, the extensive root biomass provides high potential of exploiting deeper sources of water [4]. Kudzu is a hardy plant with potential to grow even under adverse conditions such as eroded soil, low fertility, low pH and poor water holding capacity [5]. Moreover, kudzu can control soil erosion and enhance soil fertility through nitrogen fixation [6]. It was originally established in the southern states of the US to prevent soil erosion [7]. Kudzu may have the potential to be a low-input forage crop in the south-eastern United States, particularly for use as supplement during periods of drought or in late summer and early autumn when the quality of warm-season grasses is reduced [8]. Kudzu is palatable, and has given first-rate results as a pasture for beef and dairy cattle; and results showed no difference in the color or flavor of milk produced from cows consuming it [9]. Kudzu can be grazed, cut for cut-and-carry feeding systems or mixed with grass to make good quality silage. It was estimated that kudzu which stands in Alabama has the potential to yield about $5 \mathrm{t} / \mathrm{ha} /$ year of carbohydrates [10]. The relatively high carbohydrate concentration in kudzu can be viewed as an additional economic benefit as a potential source of biofuel and as a source of starch for consumption. The overall characteristics of the kudzu especially as an easy crop to be established in different areas with different soil quality and low maintenance upkeep make this crop an attractive alternative to other common forage crops. Additionally, kudzu may be well suited for use as a protein bank or as an emergency feed supply during periods of drought [8]. The objective of this study was to evaluate the nutrition value of kudzu as an animal feed.

\section{Materials and Methods}

To determine the forage quality of kudzu, shoots were harvested from naturally growing vine in three selected areas within Jacksonville, Alabama (USA). Three randomly selected shoots from each of the crops were analyzed according to the procedures of Auburn University Soil and Plant Testing Laboratory [11]. Kudzu shoots were separated into leaves and stems and analyzed separately. Each sample of dried plant material of about $0.5 \mathrm{~g}$ was placed into a $50 \mathrm{~mL}$ beaker. The beaker was then covered with watch glass and placed into a muffle furnace. The furnace was heated to $450^{\circ} \mathrm{C}$ and held at that temperature for 4 hours until all carbon burned off and it turned to greyish white ash. Next, $10 \mathrm{~mL}$ of $1 \mathrm{~mol} \cdot \mathrm{L}^{-1} \mathrm{HNO}_{3}$ was added and evaporated on a hot plate just until dry. Then, $10 \mathrm{~mL}$ of $1 \mathrm{~mol} \cdot \mathrm{L}^{-1} \mathrm{HCl}$ was added to dissolve the residue. Next, the solution was warmed nearly to a boil and transferred to a $100 \mathrm{~mL}$ volumetric flask, where it was then filtered with water. Finally, Inductively-coupled argon plasma spectrophotometry (ICAP) was used to determine the elemental composition of the filtrate. This method uses radio frequency radiation to heat a flow of argon gas into a plasma by means of an induction coil. Once a sample is introduced to $5000^{\circ} \mathrm{K}-10,000^{\circ} \mathrm{K}$ argon plasma, the sample is broken down into its individual atoms and excited to emit electromagnetic radiation. The respective elements that's were tested are $\mathrm{N}, \mathrm{S}, \mathrm{P}, \mathrm{K}, \mathrm{Ca}, \mathrm{Mg}, \mathrm{Fe}, \mathrm{Mn}, \mathrm{Zn}$, and $\mathrm{Cu}$.

The forage quality is categorized into Dry Matter (DM), Crude Protein (CP), Acid Detergent Fiber (ADF), and Neutral Detergent Fiber (NDF) was analyzed using the method of Van Soest et al. [12]. Samples of $0.5 \mathrm{~g}$ of dry tissues of each of the selected crops were heated to a boil in a beaker of $100 \mathrm{ml}$ of Neutral Detergent Solution (ND) and $50 \mu 1$ of amylase. The individual sample was boiled for 1 hour then filtered with Whitman 54 paper. Sequential analysis of NDF and ADF were then corrected for ash. The crucible containing the fiber preparation was then analyzed using a Tecator fiber apparatus. Crude protein was calculated from the following formula: $\mathrm{CP}(\mathrm{N} \times 6.25)$.

\section{Results and Discussion}

Kudzu leaves showed significantly higher dry matter and crude protein content than the stems; whereas, ADF fiber was significantly lower in the leaves (Table 1). However, NDF and total digestible nutrients (TDN) were similar in the leaves and the stems. Acid Detergent Fiber measures the cellulose and lignin of the cell wall, which helps to estimate the forage digestibility. It is quickly fermented and solubilized in the rumen [13]. The ADF content is commonly used to predict the energy content of the forage [14]. As the lignin component increases with maturity, ADF increases and the digestibility and quality of the forage decrease. Legumes have higher energy at all maturity stages compared to grasses, and have a lesser decline in energy content with maturity [15]. Neutral detergent fiber and ADF are a good measurement for quality animal feed [16]. The NDF is a 
measure of hemicelluloses, cellulose, and lignin, which estimates the forage intake [15]. As kudzu matures, the stems become more fibrous due to the increased levels of lignin content and the NDF levels increase. At high NDF concentrations in diets, rumen fill limits dry matter intake (DMI) whereas, at low NDF concentrations, energy intake feedback inhibitors limit DMI [17]. Neutral detergent fiber is the best method to separate structural and nonstructural carbohydrates in plants, and it measures most of the chemical compounds generally considered to comprise fiber [17]. Although cows appear to be able to tolerate diets with 25\% NDF and 19\% NDF from forage, those recommendations are for very specific situations and can be modified depending on the stage of development and/or period of lactation [18]. This indicates that the buffering capacity would not be sacrificed by using kudzu as a primary forage source.

The total digestible nutrients consist of digestible fiber, protein, lipid, and carbohydrate components. The average total digestible nutrient value given by the National Research Council for legume forages of all hay samples is $58.9 \%$. The TDN value for kudzu stem is $55.99 \%$, which falls below but within the recommended range. According to this criteria, kudzu leaves and stems can be considered a good quality source for TDN with the leaf as the better source than the stem (Table 1). Crude protein content is a measurement of the total amount of nitrogen in the feed source and the content reflects maturity of forage as well as fertilization amount. The CP is defined as the nitrogen content $\times 6.25$. The definition is based on the assumption that the average $\mathrm{N}$ content of feed is $16 \mathrm{~g}$ per $100 \mathrm{~g}$ of protein [17]. As forages mature, their crude protein is diluted with increasing fiber content, therefore good quality forages generally have higher protein content [19]. Crude protein is used because rumen microbes can convert non-protein nitrogen to microbial protein that can then be used by the animal [16]. With too little protein in the diet, the bacteria will not efficiently digest roughages, while with too much protein in the diet, the protein will be deaminated and become overly needed [17]. In general, forages that contain less than 70\% NDF and more than 8\% crude protein will contain enough digestible protein and energy, vitamins, and minerals to maintain older animals [16]. Based on these criteria, kudzu leaves can be considered better quality forage sources than the stem. The leaf part of kudzu was especially rich in CP and meets the requirements and recommendations for most ruminants [18].

Macronutrients concentration between the stem and leaf of kudzu, nitrogen, calcium, and magnesium showed a significantly higher in the leaf than the stem (Table 2). However, phosphorous was similar in concentration in the stem and the leaf and potassium was higher in the stem. Of the micronutrients tested, iron was significantly higher in the leaf whereas manganese, zinc, and copper showed were similar in both plant parts (Table 3).

The macronutrients selected for evaluation consist of calcium, phosphorous, potassium, and nitrogen. Calcium is the most abundant mineral in the body and constitutes nearly $98 \%$ of the bones. The remainder of the Ca's function is to control membrane permeability and important extracellular functions [17]. Forages are good sources of calcium and legumes are higher in calcium content than grasses. Depending on the stage of development, cattle can develop rickets or osteomalacia from deficient stores of calcium and phosphorous as well. The suggested range of calcium is $0.17 \%-1.53 \%$ and kudzu falls higher in that range with $1.11 \%$ DW. Phosphorous is a component of phospholipids, which is the key to major metabolic functions throughout the body. Since legumes contain higher levels of calcium, phosphorous supplementation is generally needed in forage-based diets [20]. In grazing livestock, phosphorus deficiency has been described as the most prevalent mineral deficiency throughout the world [21]. A deficiency of phosphorous results in decreased growth rates, insufficient feed utilization, anestrus, weak and fragile bones, and reduced milk production [17]. Though supplemented calciumphosphorous ratios are typically 1 to 1 , comparable results have been found with ratios of 1 to 7 [17]. Kudzu has a 7.4 to 1 calcium-phosphorous ratio. Cattle have a greater need for potassium $(0.6 \%$ to $0.7 \% \mathrm{~K})$ than any other element, though it is typically not required for supplementation since it is abundant in various feeds [22]. Forages typically contain between $1 \%$ and $4 \%$ potassium, therefore they are a good food source when other sources of potassium are low. Kudzu has a value of $1.78 \%$ DW. Magnesium is the prime mover in the initiation of many metabolic enzymes and pathways, and also is important in neuromuscular function [20]. Deficiencies in Mg, such as grass tetany, happen when levels fall below $0.12 \%$, however legume-based hays generally have around $0.27 \%$ to $0.33 \% \mathrm{Mg}$. Kudzu has a value of $0.43 \%$ DW. Forage legumes have a symbiotic relationship with bacteria that transfer atmospheric nitrogen directly to the legume and its surrounding plants [23]. This allows grasses to obtain optimum yields and quality that is required by hay fields and pastures receiving large amounts of nitrogen. Nitrogen is typically the first limiting factor in grass production and the bacteria will produce less $\mathrm{N}$ if it is provided via fertilization. It is important to inoculate legumes with proper N-fixing bacteria if that particular crop has not been grown in the field for several years [24]. 
Table 1. Comparison between kudzu stem and leaf nutritional value.

\begin{tabular}{cccccc}
\hline Treatment & Dry matter (\%) & Crude protein (\%) & Fiber NDF (\%) & Fiber ADF (\%) & Total digestible nutrients (TDN) (\%) \\
\hline Stem & 18.30 & 10.71 & 58.67 & 44.33 & 49.37 \\
Leaf & 26.17 & 24.46 & 44.00 & 28.67 & 55.99 \\
F-value & $7.34^{*}$ & $14.08^{*}$ & 4.00 & $6.11^{*}$ & 4.94 \\
\hline
\end{tabular}

CP measures the nitrogen content, including both true protein and non-protein nitrogen. TDN: The sum of digestible fiber, protein, lipid, and carbohydrate components. ${ }^{*}$ Significantly different at $\mathrm{P}=0.05$.

Table 2. Comparison between kudzu stem and leaf macronutrient concentrations.

\begin{tabular}{cccccc}
\hline Treatment & Nitrogen (\%DW) & Potassium (\%DW) & Phosphorous (\%DW) & Calcium (\%DW) & Magnesium (\%DW) \\
\hline Stem & 1.71 & 2.28 & 0.13 & 0.52 & 0.35 \\
Leaf & 3.91 & 1.28 & 0.17 & 1.69 & 0.51 \\
F-value & $14.1^{*}$ & $5.5^{*}$ & 0.83 & $7.8^{*}$ & $15.01^{*}$ \\
\hline
\end{tabular}

*Significantly different at $\mathrm{P}=0.05$.

Table 3. Comparison between kudzu stem and leaf micronutrients (trace) concentrations.

\begin{tabular}{ccccc}
\hline Treatment & Iron $(\mathrm{ppm})$ & Manganese $(\mathrm{ppm})$ & Zinc $(\mathrm{ppm})$ & Copper $(\mathrm{ppm})$ \\
\hline Stem & 28.33 & 23.00 & 32.33 & 19.0 \\
Leaf & 73.67 & 106.67 & 50.33 & 18.3 \\
F-value & $12.14^{*}$ & 3.33 & 1.73 & 1.5 \\
\hline
\end{tabular}

* Significantly different at $\mathrm{P}=0.05$.

The micronutrients selected for evaluation in this study consist of Fe, Mn, Zn, and $\mathrm{Cu}$. Iron is used in chlorophyll and protein formation, enzyme systems, respiration, photosynthesis, and energy transfer [24]. Deficiencies in Fe occurs when an imbalance of metallic ions, excessive amounts of phosphorous, and a combination of high $\mathrm{pH}$, high lime, cool temperatures and high levels of carbonate in the root zone [24]. The general mineral requirement of iron is $50 \mathrm{ppm}$ per unit of dry matter and kudzu leaves have a value of $73.67 \mathrm{ppm}$ [25]. Manganese requirements for ruminants are low with the recommended range between 10 and $30 \mathrm{ppm}$ of dry matter, resulting in rare deficiencies in cattle. Deficiencies are often characterized by reproductive disorders. Furthermore, calves born to manganese-deficient cows tend to have deformed legs [22]. Kudzu has $64.84 \mathrm{ppm}$ of Mn per unit of dry matter which well exceeds the nutrient minimum requirements. Zinc is plays a role in starch formation, protein synthesis, root development, growth hormones, hoof health, and enzyme systems and the requirements of beef cattle are about 30 ppm of daily dry matter [22] [24] [25]. The signs of deficiency include reduced feed intake and weight gain, rough hair coat, stiffness of joints, dry and scaly skin, and the nose and mouth become inflamed and submucosal hemorrhaging can occur [20]. Forages average levels of $20 \mathrm{ppm}$, but kudzu shows to have a higher level of $41.33 \mathrm{ppm}$. Copper functions as a component of enzymes such as lysyl oxidase, cytochrome oxidase, superoxide dismutase, ceruloplasmin, and tyrosinase [21]. Requirements of copper are at least $4 \mathrm{ppm}$ but can exceed up to $15 \mathrm{ppm}$ due to increased levels of molybdenum and sulfur [17]. Copper deficiencies are quite common in the United States and the signs of deficiencies include a depraved appetite, loss of condition, stunted growth, rough hair coat, anemia, diarrhea, depigmentation of hair, and sudden death [22]. Legumes are usually higher in copper than grasses and kudzu contains $18.65 \mathrm{ppm}$. The maximum tolerable concentration of copper for cattle has been estimated at $100 \mathrm{mg} \mathrm{Cu} / \mathrm{kg}$ diet [26]. In general evaluation of the macro and micro nutrient concentration in the different parts of kudzu, it appeared higher or near equal what was recommended by National Research Council [17].

\section{Conclusion}

In conclusion, kudzu can be considered a good source for animal feed, especially the leaf, which shows a higher 
value in most of the determined criteria in comparison to what was recommended by the National Research Council. This should provide a new outlook to kudzu, which has been considered a noxious weed and help in the utilization of kudzu in a positive way in the southern region of the US.

\section{References}

[1] Pierre, W.H. and Bertram, F.E. (1929) Kudzu Production with Special Response to Influence of Frequency of Cutting on Yields and Formation of Root Reserves. Journal of the American Society of Agronomy, 21, 1079-1101. http://dx.doi.org/10.2134/agronj1929.00021962002100110007x

[2] Forseth, I.N. and Teramura, A.H. (1987) Field Photosynthesis, Microclimate and Water Relations of an Exotic Temperate Liana, Pueraria lobata, Kudzu. Oecologia, 71, 262-267. http://dx.doi.org/10.1007/BF00377293

[3] Sasek, T.W. and Strain, B.R. (1988) Effects of Carbon Dioxide Enrichment on the Growth and Morphology of Kudzu (Pueraria lobata). Weed Science, 36, 28-36.

[4] Schnoor, J.L., Licht, L.A., McCutcheon, S.C., Wolfe, N.L. and Carreira, L.H. (1995) Phytoremediation of Organic and Nutrient Contaminants. Environmental Science \& Technology, 29, 318A-323A. http://dx.doi.org/10.1021/es00007a747

[5] Lynd, I.Q. and Ansman, T.R. (1990) Exceptional Forage Regrowth, Nodulation and Nitrogenase Activity of Kudzu (Pueraria lobata (Willd.) Ohivi) Grown in Eroded Dougherty Loam Subsoil. Journal of Plant Nutrition, 13, 861-885. http://dx.doi.org/10.1080/01904169009364122

[6] Tsugawa, H. (1986) Cultivation and Utilization of Kudzu-Vine (Pueraria lobata Ohwi). Journal of Japanese Grassland Science, 32, 173-183.

[7] Corley, R.N., Woldeghebriel, A. and Murphy, M.R. (1997) Evaluation of the Nutritive Value of Kudzu (Pueraria lobata) as a Feed for Ruminants. Animal Feed Science and Technology, 68, 183-188. http://dx.doi.org/10.1016/S0377-8401(97)00038-2

[8] Terrill, T.H., Gelaye, S., Mahotiere, S., Amoah, E.A., Miller, S. and Windham, W.R. (2003) Effect of Cutting Date and Frequency on Yield and Quality of Kudzu in the Southern United States. Grass and Forage Science, 58, 178-183. http://dx.doi.org/10.1046/j.1365-2494.2003.00369.x

[9] Sturkie, D.C. and Grimes, J.C. (1939) Kudzu; Its Value and Use in Alabama. Agricultural Experiment Station of the Alabama Polytechnic Institute, Circular, 83, 1-20.

[10] Sage, R.F., Coiner, H.A., Way, D.A., Runion, G.B., Prior, S.A., Torbert, H.A., Sicher, R. and Ziska, L. (2009) Kudzu (Pueraria montana (Lour.) Merr. Variety Lobata): A New Source of Carbohydrate for Bioethanol Production. Biomass \& Bioenergy, 33, 57-61. http://dx.doi.org/10.1016/j.biombioe.2008.04.011

[11] Hue, N.V. and Evans, C.E. (1986) Procedures Used for Soil and Plant Analysis by the Auburn University Soil Testing Laboratory. Department of Agronomy and Soil Publication Series 106.

[12] Van Soest, P.J., Robertson, J.B. and Lewis, B.A. (1991) Methods for Dietary Fiber, Neutral Detergent Fiber and Nonstarch Polysaccharides in Relation to Animal Nutrition. Journal of Dairy Science, 74, 3583-3597. http://dx.doi.org/10.3168/jds.S0022-0302(91)78551-2

[13] Allen, M. (1996) Fiber Requirements for Dairy Cattle: How Low Can You Go? Mid-South Ruminant Nutrition Conference Proceedings.

[14] Beauchermin, K. (1996) Using ADF and NDF in Dairy Cattle Diet Formulation-A Western Canadian Perspective. Animal Feed Science and Technology, 58, 101-111. http://dx.doi.org/10.1016/0377-8401(95)00877-2

[15] Van Soest, P.J. (1994) Nutritional Ecology of the Ruminant. 2nd Edition, Cornell University Press, Ithaca.

[16] Ball, D.M., Collins, M., Lacefield, G.D., Maitin, N.P., Mertens, D.A., Olson, K.E., Putnam, D.H., Undersander, D.J. and Wolf, M.W. (2001) Understanding Forage Quality. American Farm Bureau Federation Publication 1-01, Park Ridge, 1-15.

[17] National Research Council (NRC) (2000) Nutrient Requirement of Dairy Cattle. 7th Revised Edition, National Academy of Sciences, Washington DC.

[18] National Research Council (NRC) (1988) Nutrient Requirement of Dairy Cattle. 6th Revised Edition, National Academy of Sciences, Washington DC, 90-110.

[19] Van Saun, R.J., Idleman, S.C. and Sniffen, C.J. (1993) Effect of Undegradable Protein amount Fed Prepartum on Postpartum Production in First Lactation Holstein Cows. Journal of Dairy Science, 76, 236-244. http://dx.doi.org/10.3168/jds.S0022-0302(93)77342-7

[20] Ward, M. and Lardy, G.P. (2005) Beef Cattle Mineral Nutrition. NDSU Extension Service.

[21] McDowell, L.R. (1992) Minerals in Animal and Human Nutrition. Academic Press, New York.

[22] Petty, W.P. and Cecava, M.J. (1995) Beef Cattle Feeding and Nutrition. Animal Feeding and Nutrition, 2nd Edition, 
Academic Press, New York, 37-51.

[23] Cunha, T.J. and McDowell, L.R. (2012) Nutrition of Grazing Ruminants in Warm Climates. Academic Press, New York.

[24] Oldham, J.L. (2012) Nutrient Deficiencies in Forage Crops. Mississippi State University Extension Service Publication 1466.

[25] National Research Council (1984) Nutrient Requirements of Domestic Animals, Nutrient Requirements of Beef Cattle. 6th Edition, National Academy of Sciences, National Research Council, Washington DC.

[26] National Research Council (1980) Mineral Tolerance of Domestic Animals. National Academy of Sciences, National Research Council, Washington DC. 